\title{
Implementasi Sistem Komputerisasi Haji Terpadu (Siskohat) dalam Transparansi Informasi kepada Calon Jemaah Haji
}

\author{
Herni Yuliani, Ahmad Sarbini, \& Herman \\ Jurusan Manajemen Dakwah, Fakultas Dakwah dan Komunikasi, \\ UIN Sunan Gunung Djati, Bandung \\ Email: herni.yuliani@student.uinsgd.ac.id
}

\begin{abstract}
ABSTRAK
Penelitian ini berfokus untuk mengetahui peran dan fungsi Siskohat, program Siskohat dan sosialisasi yang dilakukan oleh Siskohat dalam memberikan transparansi informasi kepada calon jemaah haji. Metode yang digunakan dalam penelitian adalah metode deskriptif. Hasil penelitian menunjukan bahwa peran Siskohat yang utama adalah sebagai pemberi informasi. Implementasi Siskohat dapat dilihat dari layanan program yang dijalankan oleh Siskohat sehingga mengsilkan informasi yang relavan sesuai dengan kebutuhan jemaah haji. Selain itu, hasil penelitian ini memperlihatkan proses transparansi yang dilakukan oleh Siskohat yang berada dibawah lembaga pemerintahan itu berarti menunjukan usaha dari pemerintah dalam upaya memberikan pelayanan optimal bagi masyarakat khusnya dalam hal ini adalah jemaah haji.
\end{abstract}

Kata Kunci: Siskohat, Transparansi, Informasi, Jemaah Haji

\begin{abstract}
This study focuses on knowing the role and function of Siskohat, the Siskohat program and the socialization carried out by Siskohat in providing information transparency to prospective pilgrims. The method used in the research is descriptive method. The results show that the main role of Siskohat is as a provider of information. The implementation of Siskohat can be seen from the program services run by Siskohat so as to produce relevant information in accordance with the needs of pilgrims. In addition, the results of this study show that the transparency process carried out by Siskohat which is under government institutions means showing the efforts of the government in an effort to provide optimal services for the community especially in this case is the pilgrims.
\end{abstract}

Keywords: Siskohat, Transparency, Information, Haij Pilgrims

\section{PENDAHULUAN}

Peningkatan jumlah jemaah haji Indonesia setiap tahunnya merupakan tantangan yang cukup berat bagi pemerintah ini berkaitan dengan pengelolaan jemaah haji di Indonesia. Mengacu kepada jumlah jemaah haji yang setiap tahunnya semakin meningkat, ini juga berkaitan dengan penyelenggaraan ibadah haji, yang 
didalamnya terdapat prosedur mulai dari pendaftaran hingga pemberangkatan, yang semuanya harus diinformasikan kepada calon jemaah haji dengan jelas, agar calon jemaah haji mengetahui berbagai inforamsai tentang prosedur pemberangkatan Ibadah haji. Peningkatan jemaah haji tentu juga berkaitan dengan kebutuhan jemaah haji akan informasi haji di Indonesia. Karena pada faktanya masih banyak jemaah haji yang masih tidak mengetahui tentang kebijakan haji dari pemerintah. Di era-modern teknologi informasi sangatlah penting bagi masyarakat kebanyakan terutama masyarakat yang telah terjun dan merasakan dampak era-modern tentu teknologi informasi sangatlah penting dan menjadi hal yang biasa dalam kehidupan sehari-hari.

Adapun yang dimaksud dengan Teknologi Informasi adalah suatu teknologi yang digunakan untuk mengolah data, termasuk memproses, mendapatkan, menyusun, menyimpan, memanipulasi data dalam berbagai cara untuk menghasilkan informasi yang berkualitas, yaitu informasi yang relevan, akurat dan tepat waktu, yang digunakan untuk keperluan pribadi, bisnis, dan pemerintahan dan merupakan informasi yang strategis untuk pengambilan keputusan. Peluang ini yang dimanfaatkan oleh perintah dalam memberikan inforamasi mengenai informasi haji, maka pemerintah meluncurkan Sistem Komputerisasi Haji Terpadu (Siskohat). Lahirnya Siskohat merupakan jawaban dari permasalahan yang terjadi pada tahun 1990 yaitu terjadinya peristiwa Mina yang menewaskan 631 jemaah Haji Indonesia. Dan untuk pertama kalinya taun 1995 terjadi over kuota yang menimbulkan waiting list Setelah ada sistem yang memberikan informasi kepada masyarakat maka pemerintah dituntut untuk memberikan trasparansi. Oleh karena itu, implementasi Siskohat sangat penting untuk mengelola berbagai data yang berkaitan dengan ibadah haji, dan menyimpannya dengan rapi dan aman sehingga akan mempermudah dalam pencarian data dan juga akan terjaga dari hilangnya berbagai data penting. Adanya Siskohat ini akan membantu masyarakat/para calon jemaah haji untuk mempermudah mereka dalam pencarian data yang mereka inginkan mengenai berbagai permasalahan yang berkaitan dengan Ibadah haji. Sehingga tidak terjadi kesalahan-kesalahan informasi, yang itu akan merugikan calon jemaah haji.

Melihat permasalah diatas mengenai masalah Sistem Komputerisasi Haji Terpadu (Siskohat) maka peneliti mengambil tempat penelitian di Kantor Wilayah Kementerian Agama Prov. Jawa Barat Bidang Haji dan Umroh yang bertempat di Jl. Jendral Sudirman No. 644 Bandung Jawa Barat $40183 .$.

Hasil penelitian mengenai latar belakang mengenai Siskohat maka peneliti mengambil tiga pokok pertanyaan penelitian yang akan dijadiakan batas dalam penelitian untuk menghasilkan penelitian yang akurat dan tepat. Yaitu: (1) Peran dan Fungsi Siskohat dalam memberikan Informasi (2) Implementasi Program Siskohat dalam memberikan informasi (3) Sosialisasi yang dilakukan oleh Siskohat dalam memberika iinformasi yang semuanya berojek kepada calon jemaah haji.

Berdarkan fokus penelitian mengenai Implementasi Sistem Komputerisasi dalam memberikan transiparansi informasi kepada calon jemaah haji. Agar dapat 
terungkap secara keseluruhan dengan latar ilmiah. Maka peneliti mengguanakn metode deskriptif. Metode deskriptif adalah deskriptif, yaitu metode yang digunakan untuk menggambarkan atau menganalisis suatu hasil penelitian tetapi tidak digunakan untuk membuat kesimpulan secara lebih luas. Karena tujuan pokok dari penelitian ini adalah untuk menggambarkan dan memberikan penjelasan tentang penerapan Siskohat dan memberikan gambaran mengenai transparansi yang dilakukan oleh Siskohat. Penelitian ini dilakukan dengan menempuh langkah-langkah: Lokasi Penelitian, Metode Penelitian, Jenis data, Sumber Data,Teknik Pengumpulan Data, Analisis Data.

Teori yang digunakan yang berfokus pada Implementasi. Teori implementasi yang diambil dari karya Pressman dan Wildavsykan yang mengatakan bahwa sejauhmana implementasi dapat dikatakan berhasil tergantung pada keterkatian antara berbagai organisasi dan departemen pada tingkat lokal.

Informasi merupakan hasil dari pengolahan data, akan tetapi tidak semua hasil dari pengolahan tersebut bisa menjadi informasi, haisl pengolahn data yang tidak memberikan makan atau arti secara tidak bermanfaat bagi seseorang bukanlah smerupakan informasi bagi orang tersebut. Dari uraian tentang informasi ini ada tiga hal penting yang harus diperhatikan disini, yaitu: informasi merupakan hasil pengolahan data, memberikan makna dan arti dan berguna atau bermanfaat dalam meningkatkan kepastian.

Selanjutnya sistem yang mengambil dari buku Gordon B. Davis yang mengatakan system can be abstract or phisical. Siskohat termasuk kepada jenis dari sistem yaitu e-government. e-government mengacu pada penggunaan teknologi inforasi oleh pemerintah. Penggunaan teknologi informasi yang dapat meningkatkan hubungan antara pemerintah dan pihak-pihak lain. Penggunaan teknologi ini kemudian menghasilakan hubungan bentuk baru seperti: government to citizen (G2C), government to business (G2B), government to government (G2G), dan internal efficiency \& effectiveness (IEE). Government to citizen (G2C), adalah layanan untuk individual atau masyarakat. G2C membangun fasilitas satu pintu yang mudah ditemui dan mudah digunakan untuk semua layanan pemerintah kepada masyarakat. Government to business (G2B), adalah untuk layanan bisnis. G2B mengurangi beban kerja pengontrolan bisnis dalam laporan keuangan perusahaan pada pemerintah, perhitungan pajak, dan sebagainya dengan cara menghilangkan duplikasi pengumpul data. Government to government (G2G), adalah layanan antarpemerintah. G2G memudahkan penyelenggaraan pemerintah lokal untuk mendapatkan data partnernya. Internal effeciency \& effectiveness (IEE), adalah layangan untuk internal pemerintahan. IEE yang memanfaatkan teknologi informasi untuk mengurangi biaya administrasi pemerintahan. Metode yang digunakan dalam penelitian ini bersifat deskriptif, penelitian ini fokus mendekripsikan gejala-gejala, masalahmasalah, kejadian dan fakta yang terjadi di BAZ Kota Bandung pada saat sekarang. Metode ini juga bertujuan untuk menggambarkan secara sistematis fakta atau karakteristik mengenai Badan Amil Zakat Kota Bandung secara factual dan cermat yang berkaitan dengan salah satu aspek manajemen yaitu pengelolaan. Hal ini 
dimaksudkan untuk menggambarkan, memaparkan, dan menjelaskan data-data informasi tentang pengelolaan dan pola-pola berbasis manajemen zakat dalam rangka meningkatkan keberlangsungan dakwah melalui observasi, wawancara, dan studi kepustakaan yang menyeruluh terhadap objek penelitian.

Yang memberikan manfaat dalam memberikan pelayanan kepada Masyarakat. Diantaranya adalah (1) Pelayanan kepada masyarakat, informasi yang disediakan secara terus -menerus, tanpa harus menunggu dibukanya kantor. Informasi dapat dicari dari rumah, kantor, tanpa harus secara fisik datang ke kantor pemerintah. (2) Peningkaan hubungan antarpemerintah, pelaku bisnis, dan masyarakat umum ada transparansi, hubungan antara berbagai pihak menjadi lebih baik. (3)Pemberdayaan masyarakat melalui informasi yang mudah diperoleh, dengan adanya informasi masyarakat belajar untuk dapat menentukan pilihannya. (4) Pelaksanaan pemerintah yang lebih efesien, koordinasi pemerintah dapat dilakukan melalui e-mail atau video conference antara pemerintah pusat dengan pemerintah daerah.

\section{LANDASAN TEORITIS}

Dalam sebuah penelitian landasan teori menjadi salah satu hal penting. Adanya landasan teori mendukung terhadap penelitian itu sendiri supaya memperkuat dalam mencari hasil penelitian yang diinginkan sesuai masalah yang ada dengan menggunakan berbagai teori yang dikemukan oleh para ahli. Dalam penelitian skripsi yang berjudul Implemtasi Sistem Informasi Haji Terpadu (Siskohat) dalam Memberikan Transparansi Informasi Kepada Calon Jemaah Haji. Maka landasan teorinya adalah sebagai berikut: implementasi, sistem, informasi, sistem informasi, dan konsep transparasi.

Implementasi diartikan sebagai pelaksanaan atau penerapan. Menurut Teori Pressman dan Wildavskymereka menyatakan bahwa sejauhmana implementasi dapat berhasil tergantung pada keterkaitan antara berbagai organisasi dan departemen pada tingkat lokal yang terlibat dalam implementasi. Karenanya kerjasama, koordinasi dan kontrol memegang peranan sangat penting. Jika tindakan-tindakan bergantung rantai implementasi, maka tingkat kerjasama antar departeman yang dibutuhkan dalam mata rantai tersebut harus mendekati 100\%, karena apabila ada hubungan kerjasama dalam rangkaian mata rantai tersebut yang defisit, maka akan menyebabkan kegagalan implementasi. Rumusan Pressman dan Wildavsky ini melihat bahwa persoalan implementasi dan kemungkinan tingkat keberhasilannya bisa dianalisis secara matematis.

Sedangkan menurut Hogwood \& Gunn untuk mencapai implementasi yang sempurna adalah mungkin manakala dapat mengontrol seluruh system administrasi sehingga kondisi-kondisi sebagaimana yang mereka sebutkan di atas dapat terpenuhi, meski juga menyadari bahwa kondisi demikian nyaris mustahil terjadi di dunia nyata. Namun mereka memandang bahwa proposisi-proposisi tersebut adalah syarat normative yang harus diupayakan agar implementasi 
berjalan menuju sempurna.

Dalam mendefisikan sistem terdapat dua kelompok pendekatan sistem, yaitu sistem yang lebih menekankan pada prosedur dan elemennya. Prosedurnya didefinisikan sebagai suatu urutan-urutan yang tepat dari tahapan-tahapan instruksi yang menerangkan apa yang harus dikerjakan, siapa yang mengerjakan, kapan dikerjakannya dan bagaimana mengerjakannya. Penganut pendekatan elemen adalah Davis (1985) yang mendefinisikan sistem sebagai bagian-bagian yang berkaitan yang beroperasi bersama untuk mencapai beberapa sasaran atau maksud. Sedangkan Lucas (1989) mendefinisikan sistem sebagai suatu komponen atau variabel yang terorganisir, salomg berinteraksi, saling bergantung, satu sama lain dan terpadu. Sebuah sistem mempunyai tujuan atau sasaran.

Lebih lanjut pemahaman tentang sistem pertama kali dapat diperoleh dari pengertian dan definisinya. Dengan demikian definisi ini akan mempunyai peranan yang sangat penting dalam melakukan pendekatan terhadap sistem yang akan dianalisis. Pendekatan sistem yang merupakan kumpulan dari komponen atau elemen-elemen atau subsistem-subsistem merupakan definisi yang lebih luas dibandingkan pendekatan sistem yang lebih menekanakan pada prosedurnya.

Secara sederhana sistem dapat diartikan sebagai suatu kumoulan atau himpunan dari usur, komponen, atau variabel-variabel yang terorganisir, saling berinteraksi, saling bergantung satu sama lain dan terpadu. Teori sistem umum (The general system theory) yang pertama kali diuraikan oleh Kenneth Boulding terutama menekankan pentingnya perhatian terhadap setiap bagian yang membentuk sebuah sistem. Teori sistem menyatakan bahwa setiap unsur pembentuk organisasi adalah hal yang penting dan harus mendapat perhatian yang utuh supaya manajer dapat bertindak lebih efektif. Yang dimaksud unsur atau komponen pembentuk organisasi disini bukan hanya bagian-bagian yang tampak secara fisik, tetapi juga hal-hal yang mungkin bersifat abstrak atau konseptual seperti misi, kegiatan, kelompok informal, dan lain-lainnya.

Secara umum tujuan sistem menurut Tatang Amirin (2001:1) adalah menciptakan atau mencapai sesuatu yang berharga, sesuatu yang mempunyai nilai, entah apa wujudnya, dan apa ukurannya. Tujuan sistem bisa lebih dari satu, dengan kata lain sistem itu mempunyai nilai tujuan ganda. Sistem pada sasarnya adalah sekelompok unsur berhubungan satu dengan yang lainnya, yang berfungsi bersama-sama untuk tujuan tertentu: (a) Setiap sistem terdiri dari unsurunsur,contoh sistem pernapasan. (b) Unsur-unsur tersebut merupakan bagaian terpadu sistem yang bersangkutan. (c)Unsur sistem tersebut bekrja sama untuk mencapai tujuan sistem. (d)Suatu sistem merupakan bagian dari sistem yang lain yang lebih besar

Informasi adalah sebuah istilah yang tepat dalam pemakaiannya secara umum. Informasi dapat mengenai data mentah, data tersusun, kapasitas sebuah saluran komunikasi dan sebagainay. Tetapi ada beberapa gagasan yang medasari pemakaian istilah "informasi" dalam sistem informasi, informasi memperkaya penyajian, mempunyai nilai kejutan, atau tidak tersangka. Dalam dunia yang tidak 
menentu, informasi mengurangi ketidakpastian. Ia mengubah kemungkinankemungkinan hasil yang diharapkan dalam sebuah situasi keputusan dan karena itu mempunyai nilai dalam proses keputusan.

Definisi umum untuk "informasi" dalam pemakaian sistem informasi adalah sebagai berikut: informasi adalah data yang telah diolah menjadi sebuah bentuk berarti bagi penerimanya dan bermanfaat dalam mengambil keputusan saat ini atau mendatang (Gordon B. Davis, 1999:27).

Jenis-jenis informasi yang dioperasikan dalam manajemen diklasifikasikan berdasarkan aspek-aspek berikut ini dipercaya (Tata Sutabri, 2005: 28-30): (a) harus memenuhi persyaratan sebagaimana dibutuhkan oleh seorang maner dalam rangka pengambilan keputusan yang harus segera dilakukan. Berdasarkan persyaratan itu informasi dalam manajemen diklasifikasikan menjadi informasi yang tepat waktu, informasi yang relevan, informasi yang bernilain dan informasi yang dapat. (b) Informasi berdasarkan dimensi waktu. Informasi berdasarkan dimensi waktu diklasifikasikan menjadi 2 (dua) macam, yaitu: informasi masa lalu dan informasi masa kini. (c) Informasi berdasarkan sasaran adalah informasi yang ditunjukan kepada seseorang atau sekelompok orang, baik yang terdapat di dalam organisasi maupun diluar organisasi. Informasi jenis ini diklasifikasikan menjadi informasi individual dan informasi komunitas.

Nilai dan kualaitas informasi ditentukan oleh dua hal, yaitu manfaat dan biaya untuk mendapatkannya. Suatu informasi dikatakan bernilai bila manfaat lebih efektif dibandingkan dengan biaya mendapatkannya. Akan tetapi, perlu diperhatikan bahwa informasi yang digunakan didalam suatu sistem informasi umumnya digunakan untuk beberapa kegunaan sehingga tidak memungkinkan dan sulit untuk menghubungkan suatu bagian informasi pada suatu masalah tertentu dengan biaya untuk memperolehnya karena sebagian besar informasi dinikmati tidak hanya oleh satu pihak di dalam perusahaan.

Suatu sistem informasi dapat didefinisikan secara teknis sebagai satuan komponen yang saling berhubungan yang mengumpulkan (atau mendapatkan kembali), memproses, menyimpan, dan mendistribusikan informasi untuk mendukung pengambilan keputusan dan kendali dalam suatu organisasi. Sebagai tambahan terhadap pendukung pengambilan keputusan, koordinasi, dan kendali, sistem informasi dapat juga membantu para manajer dan karyawan untuk meneliti permasalahan, memvisualisasikan pokok-pokok yang kompleks, dan menciptkan produk-produk baru.

Sistem informasi berisi informasi tentang orang-orang tertentu, tempattempat, dan hal-hal didalam organisasi atau dilingkungan sekitarnya. Informasi berarti data yang telah dibentuk ke dalam suatu format yang mempunyai arti dan berguna bagi manusia. Sebaliknya, data merupakan sekumpulan baris fakta yang mewakili peristiwa yang terjadi pada organisasi atau lingkungan fisik sebelum diolah kedalam suatu format yang dapat dipahami dan digunakan orang (Kenneth C. Laudon\&Jane Laudon: 2004:9-10).

Sistem Komputerisasi Haji Terpadu (Siskohat) termasuk kepada macam- 
macam Sistem Informasi yaitu e-government. E-government adalah penyelenggaraan pemerintahan dengan menggunakan teknologi informasi dan telekomunikasi untuk meningkatkan kinerja pemerintah, serta memenuhi kebutuhan masyarakat akan transparansi dan akuntabilitas informasi keuangan pemerintah dengan tujuan mencapai good governance. EGovernment dapat diaplikasikan pada legislatif, yudikatif, ataupun administrasi publik, untuk meningkatkan efisiensi internal, menyampaikan pelayanan publik, atau proses kepemerintahan yang demokratis (Cakti Indra Gunawan, 2015: 75).

Sedangkan New Zealand, yang merupakan negara kepulauan di barat daya Samudera Pasifik ini mendefinisikan: "E-Government adalah sebuah cara bagi pemerintahaan untuk menggunakan sebuah teknologi baru untuk melayani masyarakat dengan memberikan kemudahaan akses bagi pemerintah dalam hal pelayanan dan informasi dan juga untuk menambah kualitas pelayanan serta memberikan peluang untuk berpartisipasi dalam proses dan institusi demokrasi (Cakti Indra Gunawan, 2015: 76).

Target terakhir atau ultimate goal dari sebuah evolusi e-government adalah perbaikan dan peningkatan terhadap partisipasi publik dalam proses pemerintahan. Ketika berbicara mengenai target ini, hampir semua negara di dunia dalam status yang sama, yaitu dalam proses menuju pada terciptanya suasana tersebut. Publik yang merupakan kumpulan dari individu, komunitas, dan sektor swasta di dalam suatu negara dapat berpartisipasi di dalam e-government. Partisipasi publik merupakan hal yang penting karena adalah tugas utama pemerintah untuk melayani publiknya. Jenis dan ragam pelayanan beserta kinerjanya akan secara efektif dapat dicapai oleh pemerintah apabila publik sebagai pelanggannya secara aktif dilibatkan dalam proses pengambilan keputusan. Lihatlah bagaimana sering terjadi demonstrasi melawan keputusan pemerintah karena apa yang dilakukan tidak sesuai dengan harapan dan suara hati rakyat atau masyarakatnya. Melalui implementasi e-government., kolaborasi antra pemerintah publiknya dapat dilakukan dengan mudah, murah dan cepat.

Komputerisasi berasal dari kata komputer diamabil dari bahasa latin computare yang berarti menghitung. Komputer adalah sistem elektronik untuk memanipulasi data yang cepat dan tepat serta dirancang dan diorganisasikan supaya secara otomatis menerima dan menyimpan data input, memprosesnya, dan menghasilkan output dibawah pengawasan suatu langkah-langkah intruksi program yang tersimpan di memori. Komputerisasi merupakan aktivitas yang berbasis pada komputer (computer based system) (Mahdi, 2011: 29).

Konsep Transparansi dalam Good Governance. Untuk mewujudkan pertanggungjawaban pemerintah terhadap publik, maka salah satu cara dilakukan adalah dengan menggunakan prinsip-prinsip transparansi (keterbukaan). Transparansi penyelenggaraan pemerintahan memiliki arti yang sangat penting dimana masyarakat diberikan kesempatan untuk mengetahui kebijakan yang akan dan telah diambil oleh pemerintah. Bahkan dengan adanya transparansi penyelenggaraan pemerintahan tersebut, masyarakat dapat memberikan feedback 
atau outcomes terhadap kebijakan yang telah diambil oleh pemerintah (Arifin Tahir, 2011: 161).

Ini berarti bahwa transparansi dalam penyelenggaraan pemerintahan dapat memberikan makna yang sangat berarti yakni disamping sebagai salah satu wujud pertanggung jawaban pemerintah kepada rakyat, kecuali itu pula dapat menciptakan penyelenggaraan pemerintahan yang baik atau good governance dan juga dapat mengurangi kesempatan praktek kolusi, korupsi dan nepotisme (KKN). Disinilah kuncinya mengapa transparansi sangat diperlukan dalam Good Governance bahkan merupakan salah satu syarat penting. Mungkin masih segar dalam ingatan kita, bahwa salah satu yang menjadi persoalan diakhir masa masa orde baru adalah merebaknya kasus-kasus korupsi. Dan salah satu yang dapat menimbulkan dan memberi ruang gerak kegiatan ini adalah manajemen pemerintah yang tidak transparan.

Transparansi (transparency) secara harafiah adalah jelas, dapat dilihat secara menyeluruh dalam arti kata keterbukaan. Dengan demikian, transparansi dapat diartikan sebagai keterbukaan dalam melaksanakan suatu proses kegiatan. Sebagaimana disebutkan di atas bahwa tranparansi merupakan salah satu syarat penting untuk menciptakan Good Governance. Dengan adanya transparansi di setiap kebijakan tata kelola pemerintahan, maka keadilan (fairness) dapat ditumbuhkan.

Dengan demikian transparansi berarti keterbukaan pemerintah dalam memberikan informasi yang terkait dengan aktivitas pengelolaan sumber daya publik kepada pihak-pihak yang membutuhkan informasi. Dalam arti bahwa Pemerintah berkewajiban untuk memberikan informasi yang dibutuhkan baik informasi keuangan maupun lainnya yang akan digunakan untuk pengambilan keputusan ekonomi sosial dan politik oleh pihak yang berkepentingan.

Mardiasmo mengemukakan bahwa transparansi adalah keterbukaan pemerintah dalam membuat kebijakan-kebijakan keuangan daerah sehingga dapat diketahui dan diawasi oleh DPRD dan masyarakat.

Selanjutnya Tjokromidjoyo, menjelaskan bahwa transparansi yaitu dapat diketahui oleh banyak pihak (yang berkepentingan) mengenai perumusan kebijakan (politik) dari pemerintah, organisasi dan badan usaha. Good Governance tidak membolehkan manajemen pemerintahan yang tertutup.

Oleh karena good governance tidak membolehkan cara-cara yang tertutup, Gaffar dalam Arifin Tahir (2011: 163) mengemukakan bahwa ada 8 (delapan) aspek mekanisme pengelolaan anggaran negara yang harus dilakukan secara transparans yaitu sebagai berikut: (a)Penetapan posisi jabatan atau kedudukan; (b) Kekayaan pejabat publik; (c) Pemberian penghargaan; (d) Penetapan kebijakan yang terkait dengan pencerahan kehidupan ; (e) Kesehatan; (f) Moralitas para pejabat dan aparatur pelayan publik; (g) Keamanan dan ketertiban; (h)Kebijakan strategi untuk pencerahan kehidupan masyarakat.

Pengertian haji dapat dilakukan dengan dua pendekatan. Pertama, secara etimologis (bahasa), haji memiliki arti sengaja melakukan sesuatu. Kedua, secara 
terminologis (istilah), haji berarti sengaja datang ke Mekah, mengunjungi Ka'bah dan tempat-tempat lainnya untuk melakukan serangkaian ibadah tertentu dengan syarat-syarat yang telah ditetapkan (Aden Rosadi, 2011: 1).

Haji adalah berkunjung ke Baitullah (ka'bah) untuk beribadah kepada Allah SWT dengan syarat-syarat dan rukun-rukun seta beberapa kewajiban tertentu dan dilaksanakan dalam waktu tertentu. Haji merupakan rukun Islam yang kelima. Secara hukum, ibadah haji wajib dilakukan sekali seumur hidup oleh setiap muslim yang memiliki kesanggupan. Akan tetapi bagi mereka yang bernazar haji, eajib melaksanakannya (Nasaruddin Umar, 2010: 2).

Haji menurut adalah salah satu rukun Islam. Malaikat Jibril pernah berkata, "Wahai Muhammad, beri tahu aku tentang Islam." Rasulullah Saw. Berkata, "Islam adalah bersaksi bahwa tiada tuhan selain Allah, dan bersaksi bahwa Muhammad adalah utusan Allah. Selanjutnya mendirikan shalat, mengeluarkan zakat, puasa di bulan Ramadhan, dan menunaikan haji ke Baitullah (Thariq Muhammad Al- Suwaydan, 2008: 15).

Jemaah haji klasifikasikan sebagai berikut (Pusat Kesehatan Haji, 2010: 910): (a)Jemaah haji mandiri adalah jema'ah haji yang memiliki kemampuan mengikuti perjalanan ibadah hai tanpe tergantung kepada bantuan alat/obat dan orang lain. (b) Jama'ah haji observasi adalah jema'ah haji yang memiliki kemampuan mengikuti perjalanan ibadah haji dengan bantuan alat/obat dan orang lain. (c) Jama'ah haji pengawasan adalah jama'ah haji yang memiliki kemampuan mengikuti perjalanan haji dengan bantuan alat/obat. (d) Jama'ah haji tunda adalah jama'ah haji yang kondisi kesehatannya tidak memenuhi syarat untuk mengikuti perjalanan ibadah haji. (e) Jamaah haji resiko tinggi adalah jama'ah haji dengan kondisi kesehatan yang secara epidemiologi beresiko sakit/mati selama perjalanan haji, meliputi (1) Jama'ah haji lanjut usia (2) Jama'ah haji penderia penyakit menular tentu yang tidak boleh dibawa keluar dari Indonesia (3) Jama'ah haji wanita hamil (4)Jama'ah haji dengan ketidak mampuan tertentu terkait penyakit kronis dan penyakit tertentu lainnya.

\section{HASIL DAN PEMBAHASAN}

Dalam Penelitian ini ada tiga permasalahan yang ditanyakan yaitu: (1) Peran dan Fungsi Siskohat dalam memberikan informasi kepada calon jemaah haji (2) Implementasi dalam bentuk penerapan progran yang dilakukan oleh Siskohat dalam rangka untuk menopang pemberian informasi kepada calon jemaah haji (3) bentuk transparansi yang berbentuk sosialisasi yang dilakukan oleh Siskohat guna memberikan kemudahan kepada jemaah haji dalam menggali informasi mengenai berbagai permasalah mengenai haji di Indonesia.

\section{Peran dan Fungsi Siskohat}

Ditengah upaya peningkatan pelayanan haji yang berkualitas, keberadaan Sistem Komputerisasi Haji Terpadu (Siskohat) sebagai pusat informasi sangatlah membantu, baik Pemerintah, Jemaah Haji serta para pengelola. Pengelolaan data 
semakin baik dan dapat memudahkan dalam proses pencarian data ketika akan dibutuhkan. Melalui sistem ini jemaah haji dapat mengakses berbagai informasi mengenai ibadah haji.

Keberadaan Siskohat saat ini memberikan kontribusi yang besar dalam pelayanan Haji Indonesia, Siskohat mempunyai beberapa peran dan fungsi: (1) Pendaftaran dan penyimpanan database jemaah dan petugas (2) Pemprosesan dokumen Haji (3) Penerbitan Dokumen Administrasi Perjalanan Ibadah Haji (DAPIH) (4) Pembayaran BPIH oleh BPS BPIH secara online (5) Pelaksanaan sistem akuntasnsi BPIH (6) Proses pembatalan (7) Penyusunan manifes dan kelompok terbang (kloter) (8) Pematauan (monitoring) On Time Performance (OTP) penerbangan (9) Pemantauan Kesehatan jemaah haji (10) Pemantauan Operasional Haji di Tanah Air dan Arab Saudi.

\section{Implementasi Program Siskohat}

Implemtasi Program merupakan permasalah yang selanjutnya akan di bahas. Implementasi Siskohat ini dapat dilihat dalam program yang telah dirancang oleh Siskohat guna membantu dalam memberikan bebagai kemudahan informasi bagi jemaah haji.

Sistem Komputerisasi Haji Terpadu, dalam penerapannya melibatakan banyak lembaga, seperti lembaga pemerintahan pusat, Provinsi, Kab/Kota, BPS BPIH dan pihak Kerajaan Arab Saudi. Lembaga-lembaga terkait memiliki tugas dan fungsi masing-masing. Semua lembaga tersebut saling berkaitan antara satu dengan lainnya dalam pengelolaan data jemaah haji Indonesia, yang mana data tersebut akan menjadi sebuah infomasi mengenai berbagai hal yang berkaitan dengan informasi Haji. Adapun implementasi dari Sistem Komputerisasi Haji Terpadu (Siskohat) yaitu mengenai program-progam pengolah data, program tersebut diantarnya: pendaftaran. Pelunasan, pembatalan dan dokumen haji.

Pendaftaran. Pendaftaran terdiri dari dua yaitu pendaftaran secara reguler yang langsung diberurusan dengan pemerintah dengan mengikuti syarat sebagai jemaah haji reguler. Pendaftaran haji khusus yaitu pendataran mengan ketentuan khusus serta mengikut sertakan pihak travel yang dipilih langsung oleh jemaah haji.

Banyak jemaah haji yang masil kebingungan mengenai pendaftaran sesuai ketentuan yang telah ditentukan masyarakat maka terdapat beberapa tahapan yang harus dilalui oleh jemaah haji antara lain: (a) Calon jemaah haji membuka tabungan haji pada 17 bank BPS BPIH yang telah ditentukan oleh Kementerian Agama Indonesia (b) Calon jamaah haji membawa berkas persyaratan pendafaran haji ke bidang Penyelenggara Haji Umroh di masing-masing Kemenag KabKota, diantaranya : (1) Fotocopy KTP (2) Fotocopy KK (3) Fotocopy keterangan sehat (4) Fotocopy Akte Kelahiran (5) Fotocopy Buku Nikah (7) Fotocopy Ijazah (8) Fotocopy tabungan haji (c) Calon jamaah haji mengisi blanko Surat Pendaftaran Pergi Haji (SPPH) yang disediakan di Kantor Kementerian Agama Bagian Penyelenggaraan Haji. (d) Calon Jamaah haji menyerahkan blanko Surat Pendaftaran Pergi Haji (SPPH) yang telah di isi beserta kelengkapan berkas kepada 
petugas pendaftaran haji untuk mendapatkan nomor Antri pada ruang Siskohat Online. Data dimasukan kedalam Aplikasi Siskohat Online sekaligus rekam Wajah dan Sidik Jari (Biometric). (e) Calon jemaah haji mendapatkan cetakan SPPH Siskohat Online, kemudian petugas melakukan scan persyaratan calon jamaah haji. (f) Calon jamaah haji menuju Bank BPS untuk mendapatkan nomor porsi keberangkatan haji. (g) Setelah mendapatkan Nomor Porsi Keberangkatan, Jamaah menyerahkan bukti setor dan nomor porsi tersebut ke Kantor Kementerian Agama pada Bagian Penyelenggaraan Haji dan Umrah.

Pelunasan adalah lanjutan dari pembayaran BPIH yaitu pembayaran awal yang dilakukan ketika pendaftaran. Pelunasan dalam perjalanan Ibadah Haji ini, dari data yang telah ditentukan sudah dapat diketahui siapa jemaah haji yang berhak melunasi. Pelunasan berkaitan dengan kuota yang disediakan oleh jemaah haji, karena jemaah haji yang berhak melunasi sesuai dengan urutan nomor porsi dan nanti akan disingkronkan dengan kuota yang tersedia.

Dalam masalah pelunasan banyak jemaah haji yang belum mengerti. Bahwa jemaah haji yang berhak melunasi sesuai dengan kuota yang sudah ditentukan oleh pemerintah seperti contoh: Kuota haji reguler tahun 1437H/2016 sebanyak 155.200 orang, terdiri atas Jemaah Haji sebanyak 154.049 orang dan petugas haji daerah sebanyak 1.151 orang. Maka jemaah haji yang termasuk kepada kuota tersebut maka dia jemaah haji yanag berhak untuk melunasi. Adapun ketentuannya tahapan pertama adalah (a) Bagi Jemaah Haji yang telah lunas namun menunda keberangkatan tahun-tahun sebelumnya. (b) Bagi Jemaah Haji yang telah memiliki nomor porsi dan masuk kedalam alokasi kuota Provinsi atau Kab/Kota tahun 2016 berdasarkan data Siskohat (c) Bagi Jemaah Haji nomor porsi berikutnya berdasarkan database Siskohat sebanyak 5\% yang berstatus belum haji yang masuk daftar tunggu pada tahun 2016 dari jumlah kuota Provinsi dan Kab/Kota yang bersangkutan

Pembatalan pemberangkatan dari calon jemaah haji merupakan hal yang penting. Pembatalan keberangkatan yang dilakukan oleh calon jemaah haji dengan beberapa alasan. Dalam pembatalan ini ada terbagi atas beberapa bagian ada pembatalan setoran awal, pembatalan setoran pelunasan ada juga pembatalan bagi calon jemaah haji khusus.

Dokumen haji hal yang sangat penting dalam pemberangkatan ibadah haji. Karena dalam dokumen jemaah haji terdapat identitas jemaah haji yang akan memudahkan dalam identifikasi ketika terdapat sesuatu yang tidak diharapkan. Selain itu dokumen haji menjadi pencatat jemaah haji Indonesia di Arab Saudi yang menjadi syarat dikeluarkannya izin dan tercatat sebagai jemaah haji Indonesi pemerintah Arab Saudi. Dokumen haji yang dimaksud antara lain: Paspor Jemaah Haji

Dalam pembuatan paspor seperti yang tertera dalam surat edaran Nomor : Dt.VII.II/2/H.J.00/1132/2015 terlampir bahwa pengurusan paspor kekantor imigrasi dilakukan secara kolektif oleh kementrian agama kabupaten/kota serta memaksimalkan layanan penerbitan paspor mobile pada daerah-daerah yang jarak 
tempuhnya jauh dari kantor imigrasi, namun calon jemaah haji diperkenankan untuk mengurus penerbitan paspor secara mandiri.

Mekanisme Pengurusan Paspor Jemaah Haji Dikantor Wilayah Kementrian Agama. Mekanismenya antaralain adalah: Koordinasi dengan kantor imigrasi dalam wilayah nya termasuk regionalisasi; (1) Kepala kantor wilayah kementrian agama menetapkan petugas kantor kementrian agama kabupaten kota yang akan di tugaskan dan melakukan pangambilan paspor dari kantor imigrasi sesuai usulan kepala kantor kementrian agama kabupaten/kota; (2) Menerima dan menyatukan lembar bukti setor lunas BPIH (warna merah muda) pada paspor; (3) Mengkonfirmasi dan menginput nomor paspor kedalam siskohat; (4) Melakukan updating data jemaah haji bila terdapat perbedaan nama jemaah haji atau petugas antara paspor dan bukti setoran lunas BPIH yang tidak merubah arti atau makna; (5) Mencetak identitas jemaah haji kedalam dokumen administrasi perjalanan ibadah haji (DAPIH); (6) Menempelkan pas foto dan membubuhi setempel dinas dalam dokumen administrasi perjalanan ibadah haji (DAPIH) dan panandatanganan DAPIH oleh pejabat yang berwenang (lembar sobekan); (7) Membuat nomonatif provinsi berdasarkan cabang bank Menyusun paspor berdasrkan nominatif provinsi disertai bukti setor pelunasan BPIH lembar Ke 2 (warna merah muda); (8) Pada stempel kolom isian dilembar bukti setor lunas BPIH dicantumkan nama provinsi, kabupaten, nomor nominatif dan diparaf petugas; (9) Mengantar paspor dan kelengkapan nya ke direktorat pelayanan haji untuk proses pemvisaan; (10) Mengirim paspor untuk pemvisaan ke direktorat pelayanan haji, agar diseusuaikan dengan ploting pemberankatan kloter; (11) Pengiriman dan pengambilan paspor ke atau dari direktorat pelayanan haji dilakukan dengan persyaratan sebagai berikut: a) Surat tugas atau mandat untuk pengambilan yang sudah selesai divisa; b) Surat perintah perjalanan dinas (SPPD) selama 3 hari; c) Menghitung jumlsh paspor yang telah divisa dan mencocokan nama yang dikeluarkan oleh tim penyelesaian paspor haji; d) Meneliti nama dan foto jemaah haji pada stiker visa; e) Menandatangani berita acara penyrahan paspor; f) Mengirim paspor ke embarkasi untuk kemudian diserahkan kepada jemaah haji yang bersangkutan, g) Menggabungkan paspor jemaah haji yang sudah divisa dengan DAPIH.

Pengaman Identitas Jemaah Haji. Data jemaah haji adalah data yang diperoleh dari berbagai proses yang telah dilakukan oleh jemaah haji dan yang di entry oleh petugas sehingga orang yang telah melakukan proses seperti pendaftaran diri, pelunasan perlengkapan dokumen haji maka akan tercatat sebagai calon jemaah haji dengan identitas warga negara indonesia yang legal. Sehingga bila terjadi sesuatu seperti hilang karena tidak tahu akan peta di Tanah Haram maka identitas tersebut akan membantu mencari dengan mudah. Maka pengamanan identitas jemaah haji sangatlah penting. Adapun proses yang harus dilakukan oleh jemaah haji dalam memenuhi syarat untuk pengamanan identitas haji adalah: (1) Pengamanan identitas jemaah haji dilakukan melalui scanning pasfoto jemaah haji yang masuk kuota tahun berjalan dari lembar bukti setoran 
awal BPIH; scanning ini dilakukan oleh pihak Sikohat kepada calon jemaah haji yang akan dimasukan dalam data jemaah haji yaitu dengan scanning poto maka akan mempermudah dalam mengidentifikasi jemaah haji jika sewaktu-waktu terjadi sesuatu. (2)Scanning pasfoto jemaah haji pada bukti setoran awal BPIH dilakukan untuk memastikan bahwa jemaah haji yang mendaftar sama orangnya dengan yang akan berangkat ke tanah suci. Scanning ini juga untuk memastikan keabsahan bahwa orang yang mendaftar dano orang akan berangkat sama, ini juga dilakukan untuk memastikan tidak ada kekeliruan; (3) Lembar bukti setoran awal BPIH dicetak oleh BPS BPIH sebanyak 5 lembar, masing - masing lembar diberi pasfoto ukuran $3 \times 4$ dan dibubuhi stempel BPS BPIH yang diperentukan: (4)Lembar pertama asli untuk jemaah haji; (5) Lembar kedua untuk BPS BPIH; (6) Lembar ketiga untuk administrasi pendaftaran pada Kantor Kementrian Agama Kabupaten/kota; (7) Lembar keempat untuk admistrasi pendaftaran pada kantor kementrian Agama provinsi; (8) Lembar kelima untuk admistrasi pendaftaran pada Kantor Kementrian Agama RI cq. Direktorat Jenderal Penyelenggaraan Haji dan Umrah.

Kelengkapan Paspor Jemaah Haji Identitas yang dimaksud diatas salah satunya adalah paspor ada bebrapa dokumen dalam paspor yang termasuk kepada dokumen calon jemaah haji.

Dokumen Administrasi Penyelenggaraan Ibadah Haji (DAPIH). Dapih adalah dokumen yang terdiri dari 12 lembar diperentukan bagi instansi yang berwenang baik ditanah air maupun di Arab Saudi. Dalam waktu berjalan Dapih buka seperti sebelumnya berbentuk buku dalam 12 lembar, dapih pada masa sekarang terdiri dari satu lembat yang ter belah menjadi 12 bagian yang setiap bagiannya memiliki fungsi dan peran masing-masing, yang pada waktu yang dibutuhkan maka akan di robek oleh petugas, seperti petugas imigrasi.

Dapih digunakan untuk exit/entry imigrasi, pendataan Haji Arab Saudi, pendataan Konsulat Jenderal RI dan lembar Identitas Haji. DAPIH ditandatangani oleh pejabat yang ditunjuk oleh Kepala Kantor Wilayah Kementrian Agama Provinsi dan digabungkan dengan paspor jemaah haji.

Barcode yang di tempel pada Paspor. Ada beberapa istilah Barcode atau juga stiker yang ditempel di paspor jemaah Haji ini akan menjadi identitas juga bagi jemaah haji. Stiker tersebut antara lain: a) Barcode Barcode adalah stiker yang ditempel pada paspor Haji khusus, berisikan nama penyelengara ibadah Haji Khusus tahun musim Haji berjalan dan nama Muassasah Asia Tenggara. Barcode dikeluarkan oleh kementrian Haji Arab Saudi sebagai syarat untuk mendapatkan visa dari Kedutaan Besar Kerajaan Arab Saudi, b) Stiker Musyru’ Al Madinah Al Munawarah, Stiker Musyru' Al Madinah Al Munawarah adalah stiker yang ditempel pada DAPIH lembar D utuk teknis Urusan Haji, lembar G untuk Maktab Wukula dan lembar I untuk Kementrian Haji Arab Saudi pada saat kedatangan bagi jemaah haji yang mendarat dan kembali melalui Madinah atau sebaliknya, c) Stiker Barcode Petugas Haji. Stiker baercode Petugas Hai adalah yang ditempel pada pasor petugas Haji baik Kloter maupun non Kloter pada halaman paspor 
yang berhadapan dengan lembar visa untuk dibebaskan dari biaya general service, stiker bebas biaya terdiri dari 3 bagian, yaitu: Bagian pertama untuk pembebasan biaya general service; Bagian kedua untuk Maktab Wukula Muwahhad; Bagian Ketiga untuk Kementrian Haji. d) Kartu Imigrasi Arab Saudi (Pilgrims Arrival Card dan Departure Card).Kartu ini dikeluarkan oleh Pemerintah Arab Saudi, diisi oleh setiap jemaah haji untuk pendataan Imigrasi Arab Saudi dan melekat pada karti 6 buah stiker barcode yang penempelannya diatur dibawah ini: (1) Kartu Imigrasi ini terdiri dari dua lembar (Lembar pertama adalah ARRIVAL CARD (lembar kedatangan di Arab Saudi),Lembar kedua adalah DEPARTURE CARD (lembar keberangkatan dari Arab Saudi)).

Visa Haji adalah izin tertulis yang diberikan oleh pejabat yang berwenang pada perwakilan Kerajaan Arab Saudi yang ditetapkana oleh pemerinatah Kerajaan Arab Saudi yang memuat persetujuan bagi warga negara Indonesia atau warga negara asing untuk masuk dan melakukan perjalanan (ibadah Haji) kewilayah Kerajaan Arab Saudi. Pemvisaan paspor jemaah haji dilaksanakan mulai bulan Sya'ban - tanggal 25 Dzulqa'dah setiap tahunnya.

Pemberangkatan. Fungsi Siskohat dalam hal pemulangan adalah dalam hal pendataan Jemaah Haji. Dimana sistem ini memastikan jumlah Jemaah Haji yang pulang sesuai dengan jumlah Jemaah Haji yang berangkat setiap kloternya. Pemantau ini memudahkan jika sewaktu-waktu ada jumlah Jemaah Haji berkurang atau bertambah.

Jumlah Jemaah Haji berkurang ada beberapa sebab: yaitu seperti musibah seperti tahun kemarin terjadi musibah Mina, dapat di berikan informasi siapa yang mengalami musibah yang dinyatakan wafat ataupun yang dirawat di Rumah Sakit Arab Saudi. Petugas daker (daerah kerja) di Arab Saudi akan melakukan pendataan terhadap Jemaah haji yang wafat. Juga ketika jemaah haji tersebut sakit yang mengharuskannya di rawat disana maka itu akan ada kerja sama antara Kementerian Agama dan Kementerian Kesehatan, yang mana segala pembiayaan akan ditanggung oleh pemerintah sampai jemaah haji yang sakit dapat pulang dengan pernyataan layak terbang dari Kementerian Kesehatan. Pemulangan jemaah haji yang sakit akan dipulangkan melalui pesawat reguler dan semua pembiayaan ditanggung oleh pemerintah. Pelaksanaan Pemberangkatan Jemaah Haji, dengan beberapa prosedur: (a) Melaporkan waktu keberangkatan jemaah haji ke bandara kepada Kepala Seksi Pemberangkatan (b) Melakukan koordinasi dengan bidang - bidang terkait keberangkatan jemaah haji ke Bandara Halim Perdana Kusuma (c) Memerintahkan kepada Pelaksana untuk mengarahkan jemaah haji sesuai dengan alur pembernakatan yang telah ditetapkan (d) Mengarahkan jemaah Haji untuk meintasi pintu metal detector (e) Membantu ketertiban dan kelancaran jemaah haji dalam proses pemeriksaan badan dan barang bawaan (hand bag) yang dilakukan oleh petugas Angkasapura II (f) Mengarahkan jemaah Haji yang sudah meintasi pintu metal detector utnuk menaiki bis secara teratur, sesuai dengan nomor seat dan bis yang telah ditentukan oleh pihak penerbangan Saudi Arabian Airlines (g) Membantu jemaah haki untuk 
melakukan Bording didalam Bis (h)Melaporkan kepada Kepala Seksi Pemberangkatan bahwa proses bording sudah selesai (i) Memerintah kepada petugas kloter, karom dan karu untuk mengikuti pelaksanaan upacara pelepasan (j) Melaksanakan upacara pelepasan sesuai dengan jadwal yang sudah ditentukan dan ucapan selamat jalan dilanjutkan dengan pembacaan talbiyah melalui pengeras suara (k) Memerintahkan kepala Seksi Pemberangkatan dan pelaksana untuk mendampingi jemaah haji menuju Bandara Halim Perdana Kusuma (l) Membuat Berita Acara jumlah riil jemaah haji yang berangkat pada kloter berjalan dan melaporkan realisasi take - off pada sistem aplikasi siskohat (m) Melaporkan realisasi pemberangkatan kloter kepada Kabid Penerimaan dan Pemberangkatan (n) Menerima laporan hasil relaisasi pemberangkatan.

Pemulangan adalah proses terakhir dari perjalanan Ibadah Haji dan merupakan proses yang ditunggu-tunggu oleh seluruh jemaah dan keluarga Jemaah Haji yang telah menunggu sejak lama. Proses pemulangan tidak terlepas dari pengawasan pemerintah. Juga tidak terlepas dari pengawasan pendataan Siskohat.

Fungsi Siskohat dalam hal pemulangan adalah dalam hal pendataan Jemaah Haji. Dimana sistem ini memastikan jumlah Jemaah Haji yang pulang sesuai dengan jumlah Jemaah Haji yang berangkat setiap kloternya. Pemantau ini memudahkan jika sewaktu-waktu ada jumlah Jemaah Haji berkurang atau bertambah.

Jumlah Jemaah Haji berkurang ada beberapa sebab: yaitu seperti musibah seperti tahun kemarin terjadi musibah Mina, dapat di berikan informasi siapa yang mengalami musibah yang dinyatakan wafat ataupun yang dirawat di Rumah Sakit Arab Saudi. Petugas daker (daerah kerja) di Arab Saudi akan melakukan pendataan terhadap Jemaah haji yang wafat. Juga ketika jemaah haji tersebut sakit yang mengharuskannya di rawat disana maka itu akan ada kerja sama antara Kementerian Agama dan Kementerian Kesehatan, yang mana segala pembiayaan akan ditanggung oleh pemerintah sampai jemaah haji yang sakit dapat pulang dengan pernyataan layak terbang dari Kementerian Kesehatan. Pemulangan jemaah haji yang sakit akan dipulangkan melalui pesawat reguler dan semua pembiayaan ditanggung oleh pemerintah.

Selain jumlah Jemaah Haji yang berkurang adapula Jemaah Haji yang bertambah di suatu Kloter. Penambahan ini seperti penambahan Jemaah Haji yang berstatus sebagai Petinggi Pemerintah yang waktu untuk pemulangannya tidak sama dengan jemaah haji pada umumnya dikarenakan tugas pemerintahan. Jemaah Haji penambah ini harus melakukan konfirmasi kepada petugas haji yang bertugas di Arab Saudi.

Semua data dan informasi yang mengenai pemulangan jemaah haji, pendataan tersebut di lakukan oleh sistem yang ada di Arab Saudi dan langsung diberikan kepada SISKOHAT, sehingga SISKOHAT dapat memberikan informasi, terkait pemulangan berapa yang pulang dan jadwal pemulangan

Proses Transparansi Sistem Kompterisasi Haji Terpadu (Siskohat). Sebelum 
membahas mengenai Sosialisasi yang dilakukan oleh Siskohat Kanwil Kemenag Jawa Barat. Pembahasan akan kembali kepada topik Siskohat. Banyak orang yang berfikir pada awal mengetahui bahwa Siskohat adalah sistem yang dapat diakses dengan mudah oleh semua kalangan. Baik itu jemaah haji atau masayrakat pada umumnya. Pada faktanya bahwa Sikohat merupakan sistem / jaringan yang berpusat disebuah tempat yang dalam bahasa Sistem Informasi disebut sebagai Server yang memiliki jaringan diseluruh indonesia. Tugas dari siskohat itu sendiri adalah, mendapatkan, memproses sehingga menjadi sebuah informasi yang dapat memudahkan para jemaah haji indonesia dalam menggali berbagai informasi yang diinginkan. Pada penjelasan mengenai peran dan fungsi diatas dijelaskan bahwa peran dan fungsi paling utama dari Siskohat adalah sebagai pemberi informasi. Data yang telah didapatkan dari sebuah proses panjang yang dilakukan oleh jemaah haji seperti pendaftaran dan lainnya akan diproses oleh Siskohat yang akan menghasilakan informasi yang mempermudah bagi calon jemaah haji.

Di era-modern seperti sekarang ini banyaknya jemaah haji walau harus menunggu bertahun-tahun dalam data pendaftar calon jemaah haji semakin meningkat. Dalam peningkatan jemaah haji ini juga berkaitan dengan semakin meningkatnya kebutuhan akan informasi haji. Ini menimbulakan takanan kepada pemerintah yang mengelola terutama bagian haji akan transparansi berbagai informasi yang dilakukan oleh jemaah haji. Maka pemerintah mengambil beberapa cara dalam memberikan keterbukaan/transparansi mengenai informasi haji, yaitu sosialisasi informasi yang dilakukan secara langsung dan dilakukan dengan memanfaatkan teknologi informasi.

Memberikan sosialisasi melalui bimbingan manasik. Sebelum membahas mengenai manasik Siskohat. Maka akan dibahas mengenai manasik haji. Manasik haji lumrah dilakukan oleh KBIH yang dipilih langsung oleh jemaah haji. Pemerintahpun menfasilitasi untuk manasik haji yang dilakukan di kabupaten dan kecamatan masing-masing calon jemaah haji. Manasik haji yang dilakukan oleh pemerintah ini atas koordinasi antara pemerintah pusat dan pemerintah daerah. Dimana telah ditentukan penjadwalannya oleh Kemenag. Dalam pelaksanaannya manasik haji langsung ditangani oleh pemerintah daerah setempat yang berkoordinasi kepada pemerintah pusat/pemerintah provinsi masing-masing. Dalam pelaksanaannya juga manasik haji ini telah ada ketentuan seperti ketentuanketentuan, SK, yang dilakukan oleh pemerintah daerah.

Sosialisasi yang dilakuakan sekaligus dengan bimbingan manasik tersebut dilakuakan selama enam kali terbagi atas dua: pertama, bimbingan manasik yang dilakukan di kecamatan yang dilakukan sebanyak empat kali pertemuan; kedua, bimbingan manasik yang dilakukan di Kabupaten yang lakukan sebanyak dua kali pertemuan. Kedua bimbingan manasik tersebut dalam pelaksanaannya juga diberikan informasi mengenai informasi haji lainya.

Dalam pelaksanaan manasik haji jemaah haji akan diberikan informasi yang diberikan oleh panitia dalam hal ini adalah pemerintah daerah dengan berbagai informasi yang dibutuhkan oleh jemaah haji. Seperti jadwal pelunasan awal dan 
lain-lain.

Sosialisasi dalam hal ini adalah transparansi yang dimaksud. Melihat pada perkembangan tekonogi yang semakin canggih maka pemerintah pemanfaatkan peluang tersebut untuk memberikan informasi kepada calon jemaah mengenai berbagai hal informasi yang dibutuhkan. Pemanfaatan tentu bersifat positif mengingat rakyat Indonesia sudah mengenal mengenai teknologi Informasi. Dalam hal informasi haji bukan jemaah haji saja bahkan kebanyakan bukan jemaah haji yang mengetahui teknologi tetapi masyarakat umum yang ingin mengetahui sekaligus melihat keterbukaan permerintah terhadap urusan haji. Pemerintah melalui data yang diperoleh dari Siskohat maka pemerintah mengakses berbagai informasi haji maka jemaah haji dapat mengakses dengan mudah di alamat website www.kemenag.go.id dalam alamat tersebut ketika dilihat masyarkat akan memperoleh informasi, seperti informasi mengenai no porsi, informasi mengenai tahun keberangkatan sampai pada grafik pembiayaan.

Selain website pemerintah memberikan kemudahan yang lebih efektif dan efisien yang cocok dengan keadaan zaman. Yaitu aplikasi yang dapat langsung didownload dari smartphone dengan nama Haji Pintar. Dalam aplikasi ini pemerintah melalui data yang di dapat dari Sikohat memberikan infomasi seperti tanggal keberangkatan beserta waktunya secara rinci hingga kepulangan dan informasi lainnya.

\section{PENUTUP}

Berdasarkan hasil penelitian yang peneliti lakukukan dengan judul "impelementasi Sistem Komputerisasi Haji Terpadu (Siskohat) dalam memberikan transparansi Informasi Kepada Calon Jemaah Haji” dapat diambil Kesimpulan sebagai berikut:

Siskohat merupakan sistem pengelola data yang dibuat pemerintahdengan dilatar belakangi oleh kejadian yang terjadi pada tahun 1990 musibah di Mina dan terjadinya over kuota yang menjadikan penumpukan jemaah haji sebagai waiting list. Ini menyebabkan pemerintah memberikan perhatian lebih terhadap penyelenggaraan haji di Indonesia. Dengan adanya kejadian tersebut dan sulitnya mengidentifikasi maka pemerintah meluncurkan Sistem Komputerisasi Haji Terpadu (Siskohat). Sebelum adanya sistem ini pemerintah sudah mempunyai pusat infomasi haji yang bersifat manual.

Proses implementasi sistem Komputerisasi Haji Terpadu terbagi atas diantaranya pertama, peran Siskohat. Peran Siskohat yaitunya adalah memberikan informasi kepada calon jemaah haji. Kedua, penerapan melalui program Siskohat. Siskohat mempunyai 6 inti program. 1) pendaftaran pendaftaran terdiri dari pendaftaran bagi Jemaah Haji reguler dan pendaftaran Jemaah Haji reguler. 2) pelunasan. Pelunasan adalah tahap lanjutan dari pendaftaran dan pembayaran awal yang menjelasakan mengenai Jemaah Haji yang berhak melunasi sesuai dengan kuota yang telah ditentukan oleh pemerintah. 3) pembatalan. Pembatalan dibagi atas dua, yaitu pembatalan bagi Jemaah Haji Reguler dan Jemaah Haji Khusus. Dalam pembatalan dijelaskan mengenai prosedur yang harus ditempuh ketika 
jemaah Haji menginginkan pembatalan keberangkatan. 4) Dokumen Haji. Dokumen haji yang dimaksud adalah paspor dan teknis pengurusan paspor serja Dokumen Administrasi Penyelenggaraan Ibadah haji (Dapih) yang menjadikan dokumen haji hal yang penting karena menjadi syarat dapat berangkat atau tidaknya jemaah haji. 5) pemberangkatan. Dalam pemberangkatan menjelaskan tentang prosedur pemberangkatan yang telah ditentukan oleh Pemerintah dan untuk pengelolaan data Siskohat. 6) pemulangan. Pemulangan hal yang ditunggu dalam hal ini Siskohat memberikan pelayanan berupa pendataan jemaah haji yang pulang, yang disesuaikan dengan pendataan keberangkatan.

Selain program inti yang diatas Siskohatpun mempunyai jaringan yang membantu memberikan pendataan akurat dan cepat sehingga dapat memberikan informasi kepada pemerintah diatanah air adalah operasional Arab Saudi sabagai sistem komputerisasi yang berada di Arab Saudi yang berjasama dengan petugas dan daker yang memberikan informasi secara cepat, sehingga memudahkan dalam memberikan informasi ketika ada kejadian di Arab saudi. Seperti musibah mina sehingga dapat di identifikasi dengan cepat.

Proses Transparansi. Pemberian informasi yang dilakukan oleh suatu lembaga pemerintahan tentu akan adanya tuntutan dari masyarakat untuk memberikan keterbukaan informasi sehingga informasi tersebut memenuhi kebutuhan masyarakat. Maka pemerintah membentuk Siskohat dalam memberikan pelayanan dalam masalah haji. Dalam memberikan transparansi Siskohat Kanwil Kemenag Provinsi Jawa Barat. Memberikan sosialisasi kepada Jemaah Haji yang dilakukan di berbagai KUA dan Kemenag Kab/kota yaitu pada acara Bimbingan Manasik. Dalam Bimbingan manasik tidak hanya diberikan informasi mengenai fiqih haji tapi diberikan berbagai informasi yang berkaitan dengan perjalanan dan teknis perjalan Ibadah Haji dari mulan perjalanan dari tanah air ke Arab Saudi dan kembali lagi ke tanah air.

\section{DAFTAR PUSTAKA}

Abu Bakr Jabir Al-jazairi 2000 Ensiklopedi Muslim. PT Darul Falah, Jakarta Timur. Aden Rosadi, 2011 Sejarah, Perkembangan dan Pemikiran Pengelola Ibadah Haji di Indonesia. CV. Arvino Raya.

Anwar Arifin, 2011 Sistem Komunikasi Indonesia. Simbiosa Rekatama Media, Bandung.

Arifin Tahir, 2011 Kebijakan Publik dan Transparansi Penyelenggaraan Pemerintab Daerah. PT. Pustaka Indonesia Press, Jakarta.

Azhar Susanto, 2009 Sistem Informasi Manajemen. Lingga Jaya, Bandung.

Cakti Indra Gunawan, 2015 Sistem Informasi Manajemen dan E-government. CV. IRDH (Research \& Publishing) Anggota IKAPI, Purwokerto.

Davis, Gordon B, 1999 Sistem Informasi Manajemen. PT Pustaka Binaman Pressindo, Jakarta Pusat.

Deni Darmawan dan Kunkun Nur Fauzi, 2013 Sistem Informasi Manajemen. Remaja 
Herni Yuliani, Ahmad Sarbini, \& Herman

Rosdakarya, Bandung.

Dewi Sadiah, 2014 Metodologi Penelitian Dakwah. CV. Mimbar Pustaka, Bandung.

Dwiyanto Agus, 2011 Manajemen pelayanan publik : peduli, inklusif, dan kolaboratif.

Gadjah mada unversity press, Yogyakarta .

Fuad Ihsan, 2003 Pengenalan Sistem Informasi. Andi Offset, Yogyakarta.

Harun Nasution, 1992 Eksiklopedia Islam Indonesia.Djembatan,Jakarta.

Irham Fahmi, 2012 Manajemen. CV Alfabeta, Bandung.

Kenneth C Laudon,. dan Jane Laudon, 2004 Sistem informasi Manajemen. Andi,

Yogyakarta.

Leo Agustino, 2012 Dasar-Dasar Kebijakan Publik. CV Alfabeta, Bandung.

Lexy J Moleong, 1996 Metodologi Penelitian Kualitatif. Remaja Rosdakarya, Bandung.

Malayu S.P Hasibuan, 2001 Manajemen. Bumi Aksara, Jakarta.

Malayu S.P.Hasibuan, 1996 Manajemen Dasar, Pengertian dan Masalah. PT Toko Gunung Agung, Bandung.

Mardi, 2011 Sistem informasi akuntansi.Ghalia Indonesia,Bogor.

Nasaruddin Umar, 2010 Haji dan Umrah. PT. Ichtiar Baru Van Hoeve, Jakarta.

Richardus Eko Indrajit, 2005 E-Government in action.Andi, Yogyakarta.

Sistem Informasi Pendaftaran Haji Terpadu (Sispenhat)

Sondang P Siagian, 2005 Sistem Informasi Manajemen. Bumi Aksara, Jakarta.

Tata Sutabri, 2005 Sistem Informasi Manajemen. Andi, Yogyakarta.

Tata Sutabri, 2013 Komputer Dan Masyarakat. CV Andi Offeset, Yogyakarta.

Tatang Amirin, 2001 Pokok-pokok Teori Sistem. PT Raja Grafido Persada, Jakarta.

Yakub, 2012 Pengantar Sistem Informasi. Graha Ilmu, Yogyakarta.

Haji.kemenag.go.id diakses pada 30 juni 2016, 16 Juni 2016

Jabar.kemenag.go.id diakses pada $30 \quad$ Mei 2016

http://lib.ui.ac.id/opac/themes/libri2/detail.jsp?id=20331744\&lokasi=lo $\underline{\mathrm{kal}}$ 